\title{
TASK-BASED APPROACH IN SECOND LANGUAGE ACQUISITION AND IN THE DIDACTICS OF TRANSLATION
}

\author{
A ABORDAGEM POR TAREFAS NA AQUISIÇÃO DE SEGUNDA LÍNGUA E NA \\ DIDÁTICA DE TRADUÇÃO
}

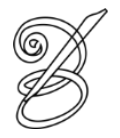 \\ Edelweiss Vitol GYSEL ${ }^{\mathrm{i}}$ \\ Federal University of Santa Catarina
}

\begin{abstract}
Studies on Second Language Acquisition (SLA) have been increasingly conducted in recent years, especially concerning the contributions of the so called task-based approach, which has been gradually undergone some adaptations, becoming a driving force for syllabus design. Within the field of Didactics of Translation (DT) the use of tasks has also, so far, proven to be an appropriate approach in the teaching and learning of translation. Therefore, in this article, I will discuss the differences regarding the rationale behind the definition of task as well as its application both in the SLA and in the DT environments. The method seeks to justify the choice of the discussed concepts, and presents the steps in the development a translation task here proposed. The discussion is grounded on this example of translation task and examines how the notion of task in SLA interfaces with the acquisition of translation competence in DT. The conclusion shows that SLA can inspire and contribute to DT concerning the task-based approach. Some of these contributions here discussed are authenticity, focus on meaning and on form, and planning. Furthermore, such contributions are applied in the development of a translation task, as a means of exemplification, and building a bridge between the areas of SLA and the DT.
\end{abstract}

Keywords: Second Language Acquisition. Task-based Approach. Didactics of Translation. Translation Competence.

Resumo: Estudos sobre a Aquisição de Segunda Língua (ASL) têm sido cada vez mais realizados nos últimos anos, especialmente no que diz respeito às contribuições da chamada abordagem por tarefas, que tem sofrido gradualmente algumas adaptações, tornando-se uma força motriz para o plano de estudos. No campo da Didática da Tradução (DT), o uso de tarefas também provou, até agora, ser uma abordagem apropriada no ensino e aprendizagem da tradução. Portanto, neste artigo, discutirei as diferenças em relação às definições de tarefa, bem como a aplicação desta, tanto no contexto de ASL quanto no contexto da DT. O método procura justificar a escolha dos conceitos discutidos e apresenta os passos no desenvolvimento de uma tarefa de tradução. A discussão baseia-se neste exemplo e examina a interface entre a noção de tarefa em ASL e a aquisição da Competência Tradutória em DT. A conclusão mostra que a ASL pode inspirar e contribuir para a DT em relação à abordagem baseada em tarefas. Algumas dessas contribuições aqui discutidas são autenticidade, foco no significado e na forma e planejamento. Além disso, essas contribuições são aplicadas no desenvolvimento de uma tarefa de tradução, como um meio de exemplificação, e na construção de uma ponte entre as áreas de ASL e de DT.

Palavras-chave: Aquisição de Segunda Língua. Abordagem por Tarefas. Didática de Tradução. Competência Tradutória.

RECEBIDO EM: 17/11/2018

ACEITO EM: 15/12/2018

PUBLICADO EM: dezembro 2018 


\section{INTRODUCTION}

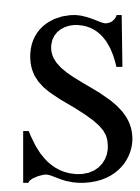

tudies on Second Language Acquisition (SLA) have been increasingly conducted in recent years, especially concerning the contributions of the so called task-based approach. Ellis (2003), Skehan (2003), and Samuda and Bygate (2008) are some of the researchers interested in defining, applying, and analyzing this approach in SLA context. According to Skehan (2003), it all started during the 1970s, when attention was given to the communicative approach as learners were encouraged to exchange information focusing on meaning, and not only structure. At this time, tasks were still referred to as communicative activity. During the 1980s, this communicative activity was replaced by the term task, and since then this new approach, gradually undergoing some adaptations, became a driving force for syllabus design. Within the field of Didactics of Translation (DT) the use of tasks has also, so far, proven to be an appropriate approach in the teaching and learning of translation. Based on frames such as the one from Hurtado Albir (1999, p. 56), who states that "Task is a unit of work in the classroom representative of translation practice, formally directed towards learning how to translate and designed with a specific objective, structure and sequence", I will discuss here

64 the differences regarding the rationale behind the definition of task as well as its application both in the SLA and in the DT environments.

According to Gonzáles Davies (2004, p. 22-23) a task can be understood as " [...] a chain of activities with the same global aim and final product. On the way, both procedural (knowhow) and declarative (know-what) knowledge are practiced and explored". Considering this statement as central in translators' education, the aim of this paper is threefold. First, I will compare some definitions of task within DT and SLA. Second, I will review the notions of authenticity, focus on form and focus on meaning, and planning in the task based approach within DT as well as SLA. Third, I will reflect on the contributions this approach can provide to DT from an SLA perspective. In this sense, the following research questions can be posed:

RQ1. How is task based approach viewed in SLA and DT?

RQ2. What is the meaning of authenticity, focus on form and focus on meaning, and planning in SLA?

RQ3. How can these concepts from SLA contribute to DT regarding the taskbased approach? 
Considering this statement as central in translator's education, the aim of this paper is threefold. First, this introduction briefly points to the importance of tasks both in SLA as in DT and poses the research questions, which guide the discussions hereafter. Second, the review of literature presents the current definitions of task in these two fields of study, and the concepts of authenticity, focus on form (Long, 1985) and on meaning, and planning (Foster \& Skehan, 1996) are displayed from an SLA perspective with the aim of establishing a dialogue with the DT perspective. Third, I will reflect on the contributions this approach can provide to DT from an SLA perspective. The method seeks to justify the choice of the discussed concepts, and presents the steps in the development a translation task here proposed. Fourth, the discussion is grounded on this example of translation task and examines how the notion of task in SLA interfaces with the acquisition of translation competence in DT. In conclusion, some final remarks and reflections close this paper.

\section{LITERATURE REVIEW}

Along the next five subsections, a literature review related to the concept, use, and contributions of task-based approach to the DT is presented. Therefore, both definitions of task are shown, first within SLA and then within the DT, as well as three well established constructs in SLA - authenticity, focus on form and on meaning, and planning - which can contribute to the understanding of the task in DT.

\subsection{Definitions of task within SLA}

The first concept of task goes back to 1987, when Prabhu proposed the use of task-based approach in secondary school classes. Within this context, he postulates that

\footnotetext{
A task is an activity which required learners to arrive at an outcome from given information through some process of thought, and which allowed teachers to control and regulate that process (Prabhu, 1987, p. 24).
}

Much has been said regarding the definition of task. Skehan (2003) explains that, on one hand, researchers see it as "a convenient or necessary means to explore theoreticallymotivated questions [...] teachers, on the other hand, and from a pedagogic perspective, understand tasks as an extended pedagogic sequence, inspired by and designed with teaching goals" (p.2). Regardless of the use of tasks, whether for research or teaching purposes, Ellis (2003), pondering on key elements and dimensions of tasks, states that definitions of task may 
vary according to a number of dimensions such as scope, perspective, authenticity, language skill, cognitive processes, and outcomes.

The scope dimension views a task as an activity a) that necessarily involves language (Nunan, 1989); b) in which meaning is primary (Skehan, 1996), and c) that calls for primarily meaning-focused language use, as opposed to form-focused language use (Ellis, 2003).

The perspective dimension can be seen from the designer's point of view, in which a task is "a workplan that is intended to engage the learner in meaning-focused language use" (Breen, 1989, p.23), and from a learner's point of view, a task is its actual performance, known as task-as-process (Breen, 1989).

The authenticity dimension, in a very broad sense, defends the correspondence of a task to some real world activity, as Long (1985) puts it, dressing a child, or painting a fence, but as such tasks are not likely to happen in a classroom environment, therefore, those having some relationship to the real world can also be considered a task. Skehan (1996) exemplifies them as describing a picture or telling a story based on pictures.

The language skill dimension assumes that a task is directed at oral skills and production of language. However, as a means of introduction, preparation and/or reflection, it does not exclude reading and listening at specific stages of the task.

According to Prabhu (1987), task performance necessarily involves cognitive processes. He states that an ideal task should engage learners in 'reasoning' or 'connecting' pieces of information, 'deducing' new information and 'evaluating' information. Doyle (1983) reinforces cognitive aspects, utilizing such examples as memory tasks, comprehension or understanding tasks, and opinion tasks.

Finally, as a conclusion or result of task performance, there should be an outcome, which could be measured in terms of content. Such an outcome might favor motivation and interest of learners so that they perform an activity with a tangible aim, and in the end, a sense of achievement is reached. Nevertheless, from a pedagogic point of view, a successful use of language is considered an outcome, for example, asking for directions without being misunderstood is a successful outcome.

All things considered, as Ellis (2003) highlights, that the definition of task can be problematic, depending on the perspective taken, this might vary considerably. From a researcher's point of view a task is a resource of data acquisition, where authenticity plays a minor role and its outcome is of major importance. In contrast, from a pedagogic perspective, a task is essentially a communicative act within a classroom environment, moved by an aim, 
and in which meaning is primary. In this paper, the pedagogic stance will be taken as central, since its purpose is to draw an interface of task between SLA the DT, which is in substance pedagogically oriented.

\subsection{Definitions of task within DT}

From DT perspective, a task is defined as "an unit of work in the classroom, representative of translation practice, formally directed towards learning how to translate and designed with a specific objective, structure and sequence" (Hurtado Albir, 1999, p. 56). As already mentioned above, Gonzáles Davies (2004, p. 22-23) specifies a task as "[...] a chain of activities with the same global aim and final product. On the way, both procedural (know-how) and declarative (know-what) knowledge are practiced and explored".

Hence, as in the SLA framework, a task also has some definitions in DT that complement each other. First it is considered "a piece of classroom work, which involves learners in comprehending, manipulating, producing or interacting in the target language while their attention is principally focused on meaning rather than form" (Nunan, 1989, p. 10). Second, an activity or action aiming at processing and understanding a language (Richards, Platt and Weber, 1986). Third, any action structured for learning a language having a specific objective, an appropriate content, a specified working process, and a wide range of possible outcomes (Breen, 1987). Here, a task must have the following characteristics: a) be representative of communication processes in real life, b) be identified as an activity unit in class, c) be intentionally directed toward learning, and d) be designed with an objective, a structure and a working sequence.

In fact, regarding the four prior characteristics, Nunan (1989) distinguishes between two kinds of tasks, the rehearsal task and the pedagogical task. The first refers to the real world, meaning that tasks are designed according to real needs of learners. The second takes into account the classroom lesson itself, and is based on the learners' learning processes. Moreover, he points out to the gradation of tasks suggesting three main aspects: the gradation of content (related to grammar and vocabulary complexity), the gradation of the learner's learning process (related to motivation, experience, and knowledge) and the gradation of the activity (related to complexity and the amount of information it offers).

In conclusion, from DT perspective, a task is performed within a learning environment (classroom and/or distant learning), is representative of the translation practice, and is specifically designed for translation learning purposes involving the declarative knowledge and 
the procedural knowledge ${ }^{\mathrm{ii}}$, having clear objectives, an evident structure, and a gradual working sequence.

\subsection{Authenticity}

Throughout the process of a task, from its design and its performance to the last reflections about it, authenticity plays an important role both in SLA as in the DT, for it may be responsible for a learner's motivation in accomplishing the given task. Authenticity in SLA means real world processes of language use (Ellis, 2003, p. 10). In a similar conception of the term, authenticity in the DT has two meanings. First, it can be a genuine translation assignment from a real client, where translation learners are to produce a target text according to the terms and conditions specified in the translation commission (Kiraly, 2000). Second, it can be a simulated translation task, "one that carries all the characteristics of an authentic translation project except that they do not have a real client" (Li, 2013, p. 13). This second one is a very useful and usually applied alternative in translation classes, since the work will be performed by learners and the terms and conditions of the client in authentic projects might not always be assured.

Regarding the use of non-authentic tasks, let us assume that a learner is given a task where he/she has to describe a picture, or translate a non-familiar text from an unknown area. If this learner finds no connection of the picture or the translation with his real world, that is, his/her personal possible real needs of language, this task will make little sense, and being of no practical use, motivation in performing the task will decrease. In contrast, if the learner is exposed to real world tasks, or actual texts, which currently circulate among translators, the motivation of task accomplishment might increase, for learners will probably be more challenged to complete the task.

\subsection{Focus on form and focus on meaning}

During the 1960's and the 1970's, methods in language pedagogy were essentially centered on the teaching of grammatical forms, therefore tasks were conceived based on two main streams a) explicit in the grammar-translation method and b) implicit in the audio-lingual method. These methods were rejected when the task based approach started to be implemented in SLA, around the late 1980's. Then, the meaning focused task was the primary goal, for this approach was interested in the exchange of language as meaning and not as an object. 
In 1991, Long, inspired by behaviorist psychology and structuralist linguistics, first proposed the concept of task focused on form as being "a task focusing on language as object" (Long, 1999, p. 45). Based on his own studies (1983) and the research done by Lightbown (1983) and by Pica (1983), he advocated the teaching of linguistic items, such as structures, notions, lexical items, etc. within a task, stating that this kind of instruction helps learners not only to speed up the rate of learning, but it is also beneficial to long-term accuracy and "raises the ultimate level of attainment" (Long, 1991, p. 45).

In 1998, Widdowson argued that the difference between these two forms of instruction lies in the kind of meaning learners want to exchange - the pragmatic meaning, achieved through communicative tasks, or the semantic meaning, achieved through language exercises. More recently, Ellis (2000) distinguished both forms in terms of how language is viewed. When there is a focus on meaning, language is viewed as a tool and the learner is a user, and when there is a focus on form, language is an object and the learner is a student.

It is important to highlight that both forms, focused on form and focused on meaning, can be applied interchangeably in a task-based approach. They might also complement each other enriching the learner's learning process.

\subsection{Planning}

Ellis (2005, p. 3) states that, "planning is basically a problem solving activity" and it is required as soon as spoken or written language is used, helping the speaker or writer to decide how to produce understandable speech. He distinguishes between two kinds of task-based planning: pre-task planning and within-task planning. The first is divided into rehearsal planning, where learners can perform the task before the actual performance, and strategic planning, where learners can prepare to perform the task in terms of content and how to express it. The second is also differentiated in terms of amount of time available for planning. Unpressured performance allows learners to carefully plan their discourse, while in pressured performance learners will have just some seconds of on-line planning. Although the kind of within-task planning used to perform a task has proven to have a strong impact on the quality of produced language (Ochs, 1979; Foster \& Skehan, 1996), only unpressured performance will be considered in this paper, since we are dealing with a written translation task, where students are given plenty of time to plan before and during task performance. 


\section{METHOD}

In this section, the justification of the choice of the three selected concepts is presented, namely, authenticity, focus on form and on meaning, and planning derived from SLA and here proposed as a contribution to DT. The description of the steps taken in the design of the exemplified task from the following section is also made.

As already mentioned in the introduction, task-based approach took its first steps within SLA in the early 1980's. It originated from the need for an open and integrative curriculum, which a) would contemplate teachers and students equally; b) would incorporate different aspects from the learning process; c) would not separate content from methodology; and d) would coherently and purposefully organize objectives and content according to methodological decisions (Hurtado Albir, 2005).

In the context of the DT, task-based approach is proving to be a very effective technique for teaching and learning of translation due to its globalizing features, which integrate all the relevant elements of a curriculum design: objectives, content, methodology and assessment (Hurtado Albir, 2005). In this sense, the above outlined concepts from SLA, namely

70 authenticity, focus on meaning and on form, and planning were selected after being studied in a course from a graduate program that presented task-based approach from a SLA perspective, and from all the analyzed aspects, these pose valuable contributions to DT. Furthermore, as a doctoral student from the Translation Studies program, my motivation for this paper is to reflect on possible interfaces between both fields.

The task proposed here is elaborated to exemplify how authenticity, focus on meaning and on form, and planning might play an important role before, during and after the performance of a translation task. It is designed based on Willis' (1996) proposition of a cycle of seven stages of task-based teaching, consisting of pre-task, task, reporting, analysis, revision, and reflection, aiming at making learners aware of the importance and the impact of text types in any translation process. Keeping this in mind, the seven stages are displayed in a sequence. Then, tables are designed with the teacher's instructions at the top followed by questions and activities to be answered and completed by the learners. The material (the text) was taken from the internet and copied into the table to be used as a simulated task. On the right, comments are made regarding teacher's as well as learners' performance at each stage of the task cycle. 


\section{DISCUSSION}

As the title of this section indicates, I want to discuss here the possible contributions of the concepts from SLA previously presented in the paper in the realm of the DT.

Considering the following task, it must be made clear that it is included in this paper only as a sample, and for the sake of clarification of possible contributions from SLA to DT.

The following task aims at simulating a real translation commission. The texts used were collected on the Internet, and are all used as propaganda or manuals of current and real market products. Before starting the task, the teacher explains that this is a simulated translation task, where the commissioner/client is represented by the teacher him/herself, therefore all the inquiries and doubts can be solved in class or by email with the teacher.

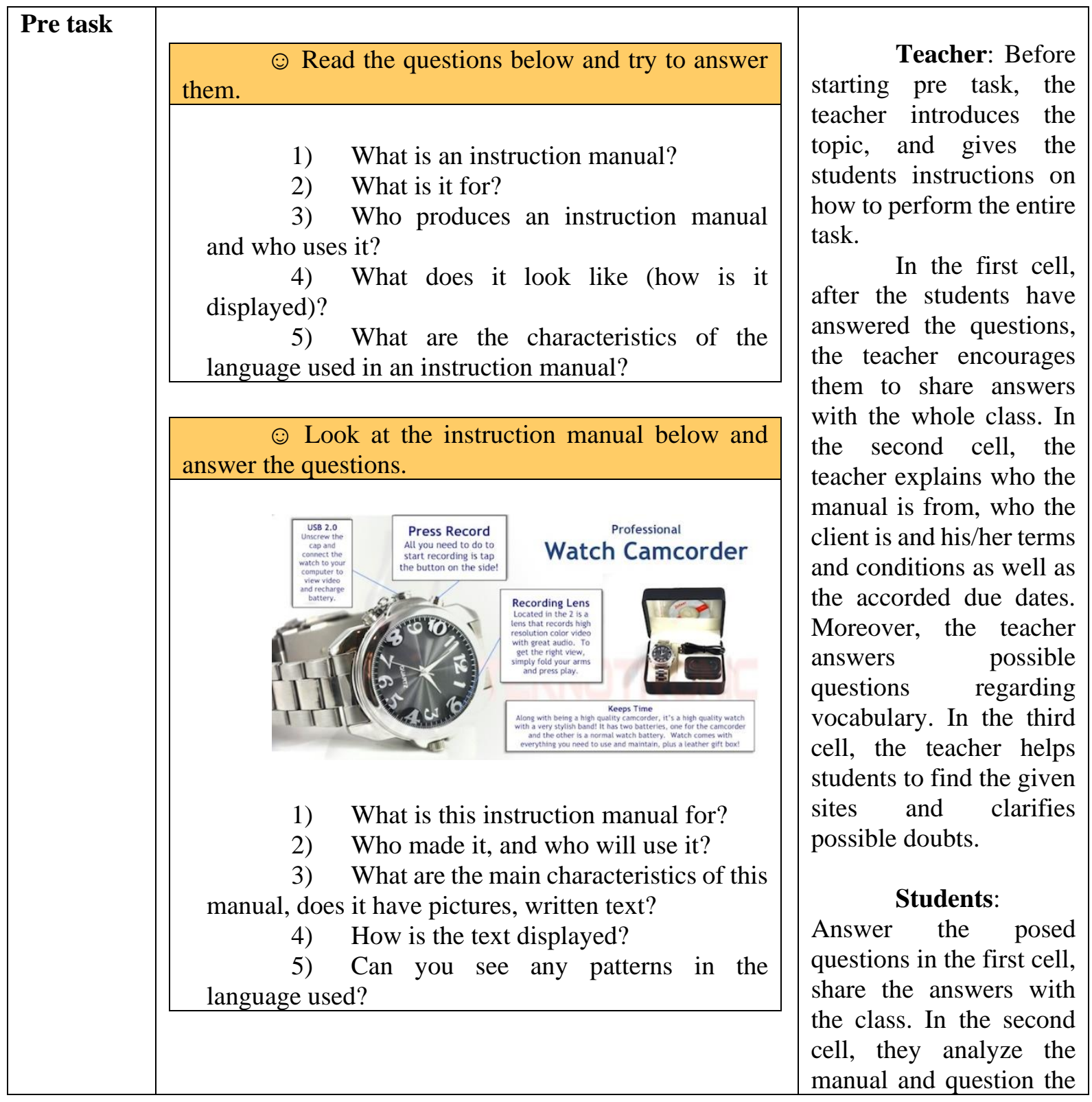




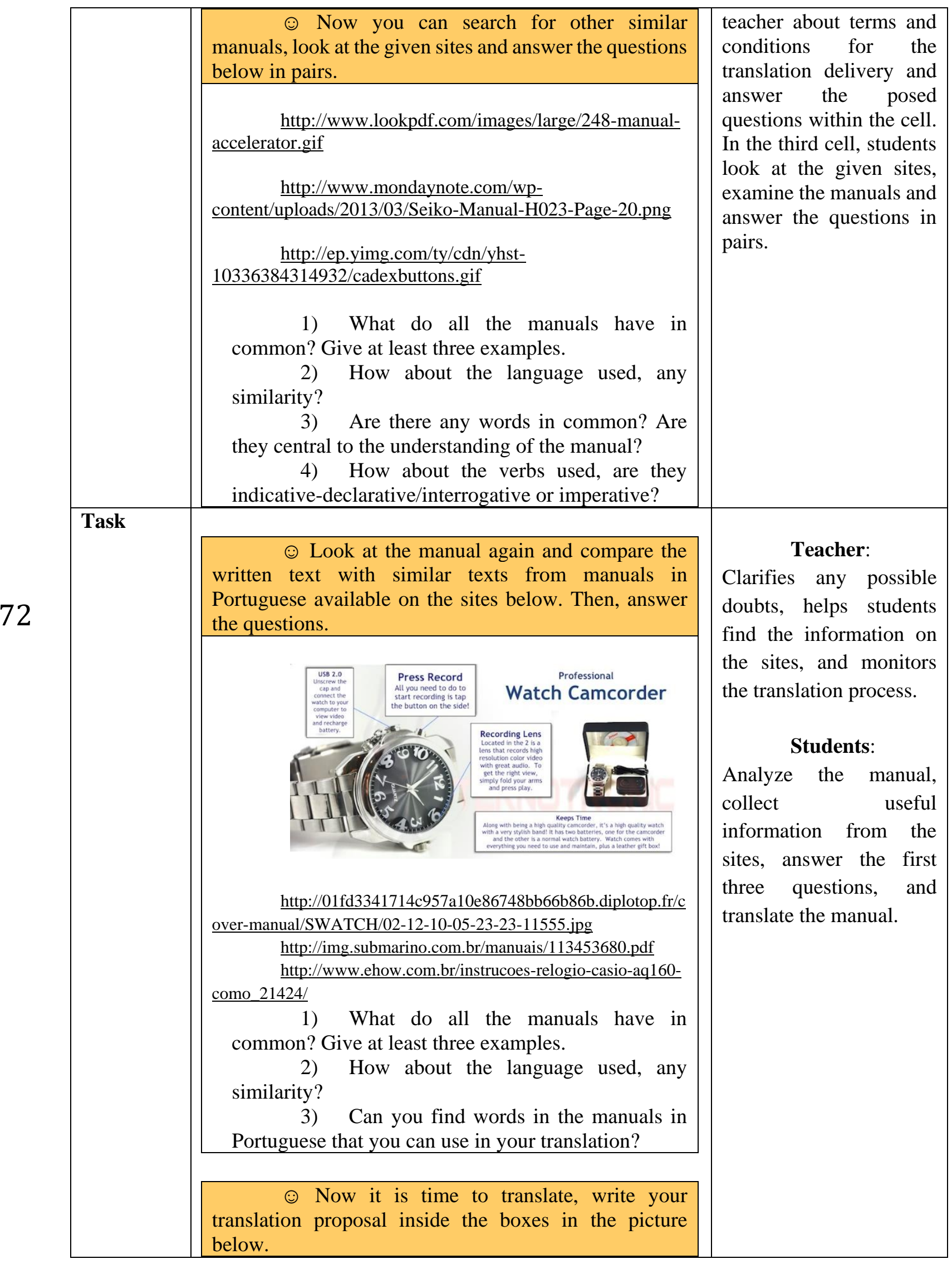




\begin{tabular}{|c|c|c|}
\hline \multirow[t]{6}{*}{ Report } & & \multirow{3}{*}{$\begin{array}{l}\text { Teacher: } \\
\text { Monitors the sharing } \\
\text { process, helps students } \\
\text { with remaining doubts. } \\
\text { Gives some feedback } \\
\text { about the observed } \\
\text { translation process. }\end{array}$} \\
\hline & (-) Answer the following questions & \\
\hline & $\begin{array}{l}\text { 1) Did you use words from the Portuguese } \\
\text { manuals in your translation? } \\
\text { 2) Where were your translation problems? } \\
\text { 3) How did you solve them? }\end{array}$ & \\
\hline & & \multirow{3}{*}{$\begin{array}{l}\text { Students: } \\
\text { Answer the first three } \\
\text { questions, share the } \\
\text { answers and discuss the } \\
\text { whole process in pairs. }\end{array}$} \\
\hline & $\begin{array}{l}\text { Now, share your above answers with your } \\
\text { pair, and reflect together on the following points. }\end{array}$ & \\
\hline & $\begin{array}{l}\text { 1) How was your translation process? } \\
\text { 2) Comparing your translation with your } \\
\text { peer's, what can you say? }\end{array}$ & \\
\hline \multirow[t]{4}{*}{ Analysis } & \multirow[b]{2}{*}{$\begin{array}{l}+ \text { In groups of three or four, compare your } \\
\text { translations and answer the following questions. }\end{array}$} & \multirow{3}{*}{$\begin{array}{l}\text { Teacher: Selects } \\
\text { some passages of the } \\
\text { translation which were } \\
\text { problematic and } \\
\text { discusses them with the } \\
\text { whole class. }\end{array}$} \\
\hline & & \\
\hline & $\begin{array}{l}\text { 1) What were the differences in your } \\
\text { translations? } \\
\text { 2) In your opinion, which were the best } \\
\text { solutions to the problematic passages? }\end{array}$ & \\
\hline & & $\begin{array}{l}\text { questions and discuss the } \\
\text { solutions found. }\end{array}$ \\
\hline \multirow[t]{4}{*}{ Revision } & & \multirow{3}{*}{$\begin{array}{l}\text { Teacher: Helps } \\
\text { students with their } \\
\text { revision. Helps them } \\
\text { with their control quality. }\end{array}$} \\
\hline & $\begin{array}{l}\odot \text { Based on your translation, answer the } \\
\text { following questions and make adjustments if necessary. }\end{array}$ & \\
\hline & \multirow{2}{*}{$\begin{array}{l}\text { 1) Based on the revision made with the } \\
\text { whole class, are there adjustments to be made in your } \\
\text { translation? } \\
\text { 2) Is your translation in consonance with } \\
\text { the requirements of the client? } \\
\text { 3) Have you made all the necessary } \\
\text { corrections? Is your translation ready to be } \\
\text { 4) Is your answer. }\end{array}$} & \\
\hline & & $\begin{array}{l}\text { Revise and edit the } \\
\text { translation. Check for } \\
\text { control quality. Finish } \\
\text { the translation to be } \\
\text { delivered. }\end{array}$ \\
\hline \multirow[t]{2}{*}{ Reflection } & & Teacher: \\
\hline & & Reflects on the whole \\
\hline
\end{tabular}




\begin{tabular}{|c|c|c|}
\hline \multirow{2}{*}{ 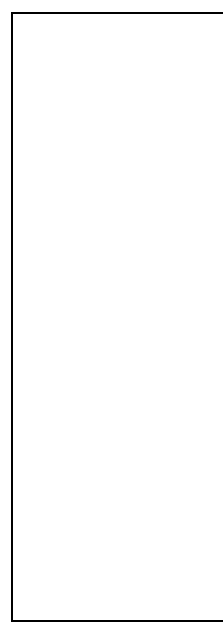 } & $\begin{array}{l}\text { Make notes about the following points and } \\
\text { share them in groups. }\end{array}$ & $\begin{array}{l}\text { process and takes notes } \\
\text { for future improvement. }\end{array}$ \\
\hline & $\begin{array}{l}\text { 1) Which were the aspects that made the } \\
\text { translation difficult? } \\
\text { 2) Which were the easy aspects? } \\
\text { 3) Were you satisfied with your solutions? } \\
\text { 4) Were the other texts from the same text } \\
\text { type helpful in your translation? } \\
\text { 5) Could you resolve all your doubts } \\
\text { regarding the translation commission? } \\
\text { 6) Has group discussion helped you? }\end{array}$ & $\begin{array}{l}\text { Students: } \\
\text { Reflect on the whole } \\
\text { translation process, the } \\
\text { pre task, the translation } \\
\text { itself, the contributions } \\
\text { of the colleagues, the } \\
\text { translation problems and } \\
\text { how they were solved, } \\
\text { and the control quality. }\end{array}$ \\
\hline
\end{tabular}

\subsection{Contributions of SLA to DT}

Here, the discussion of possible contributions of the SLA concepts of authenticity, focus on form and on meaning, and planning is presented. For this purpose, each step of the task pre-task, task, report, analysis, revision, reflection - is addressed and the interface with SLA is posed.

\section{Pre-task}

In this stage, planning is central. The learner is encouraged to reflect on the questions preparing for the main task. By answering the posed questions, the learner is able to plan and draw strategies for the performance and completion of the task. Another critical aspect is the focus on meaning. By sharing their answers, learners have to produce language and share previous knowledge with each other, and a focus on form is also required, since the learner has to detect and think about grammar and lexical structures from the text type in question. Authenticity also plays an important role. During the pre-task, the teacher explains that this is a simulated translation task and all the doubts regarding the specific vocabulary from the area, commission, due dates, payment, etc. must be directed to him/her, for the teacher represents the client.

Task

During the task, planning is required before answering the posed questions, and especially before translating, a first draft of it might serve as pre-task planning as well as strategic planning. While translating any text, the translator - here the learner - must focus on meaning and form in two languages, the source and the target language, in order to produce an 
understandable text. At this stage, authenticity is present in the selected texts; all of them are real manuals or propaganda collected from the internet.

\section{Report}

Before answering the posed questions, learners have time to strategically plan their answers and plan rehearsing what to share with the group. By reporting on passages that were problematic to them, learners have to consider the focus on meaning (semantic structures, cohesion and coherence) and on form (vocabulary and grammar structures). They also have to be aware that they are dealing with an authentic text, and, for this reason, their problems also represent authentic translation problems.

\section{Analysis}

While comparing the translations, learners can strategically plan which aspects are relevant to be shared with the group. Also, special attention must be given to language meaning and language form when comparing the groups' translations. As in the report stage, their shared solutions represent authentic answers to authentic problems.

\section{Revision}

In order to answer the questions, planning is fundamental. The quality control performed at this stage requires a focus on meaning as well as on form. The revision must be carefully made as it would be delivered to a real client, an authentic one.

\section{Reflection}

By selecting relevant information to be shared, learners are given time to plan and decide what to share with the whole class. Reflecting on the whole translation process, learners have to give attention to meaning and to form when considering the product and the original, that is, the translated text and the source text. Here, a link can be made with one of the criterial features of a task, proposed by Ellis (2003), when he refers to task as a cognitive process, which requires learners to select, classify, reason, and evaluate information. Furthermore, he says that a taskbased lesson needs to engage and help to foster metacognitive awareness in students as they are required to evaluate their performance and progress. With regard to the delivery of the work, it has to occur in similar terms as in a real delivery situation. Here, authenticity can encourage learners and empower them once they face the labor market.

\section{FINAL REMARKS}

In the context of SLA, the use of task-based approach enables learners to acquire a second language and the skills required to communicate in this language, whereas in DT, task- 
based is a useful technique for teaching and learning to translate written texts, since its ultimate goal is to develop translation competence (PACTE, 2003). Based on this difference, some adaptations have to be made when applying the task-based approach in DT. Such adaptations are, for instance, the switch of focus to the interpretation/understanding and production of written texts. These adaptations also tend to differentiate this approach from the approach in SLA regarding the elaboration, the objectives, the performance and the outcome of a task.

However, SLA can still inspire and contribute to DT concerning the task-based approach. Some of these contributions, namely, authenticity, focus on meaning and on form, and planning were here presented. They were discussed and applied in the development of a translation task, as a means of exemplification, and building a bridge between the areas of SLA and the DT.

This interface between fields of study is important not only for academic research, but especially in the realm of Didactics, where trainers and teachers should aim to improve not only their classroom environment, but their methodology and approach to teaching and learning, rewarding their students with motivation and enabling them to learn more effectively.

\section{REFERENCES}

BREEN, M. P. The evaluation cycle for language learning. In R.K. Johnson (ed.). The Second Language Curriculum. Cambridge: Cambridge University Press, 1989, pp. 187-206.

BREEN, M. P. Contemporary paradigms in syllabus design. Language teaching, 1987, 20/2, pp. 81-92, and 20/3, pp. 157-174.

DOYLE, W. Academic work. Review of Educational Research, 1983, v. 53, n. 2, pp. 159199.

ELLIS, R. Focusing on form: Towards a research agenda. Paper presented at annual Regional English Language Centre Conference, Singapore, 2000.

ELLIS, R. Task-based language learning and teaching. Oxford: Oxford University Press, 2003.

ELLIS, R. (Ed.). Planning and task performance in a second language. Amsterdam: John Benjamins, 2005.

FOSTER, P., SKEHAN, P. The influence of planning on performance in task-based learning. Studies in Second Language Acquisition, 1996, v. 18, n. 3, pp. 299-324.

GONZÁLEZ DAVIES, M. (coord.). Multiple Voices in the Translation Classroom. Amsterdam: John Benjamins, 2004. 
HURTADO ALBIR, A. Enseñar a Traducir. Metodología en la formación de traductores e intérpretes. Madrid: Edelsa, 1999.

HURTADO ALBIR, A. A aquisição da competência tradutória: aspectos teóricos e didáticos: In: Pagano, A., Magalhães, C. Alves, F. (Eds.). Competência em tradução: cognição e Discurso. Belo Horizonte: Editora UFMG, 2005, pp. 19- 57.

HURTADO ALBIR, A. Competence-based Curriculum Design for Training Translators. The Interpreter and Translator Trainer. Manchester: St. Jerome, 2007, pp. 163-195.

KELLY, D. Training the Trainers : Towards a Description of Translator Trainer Competence and Training Needs Analysis. TTR, Montréal, 2008, v. 21, n. 1, pp. 99-125. Available at: http://id.erudit.org/iderudit/029688ar

KIRALY, D. A Social Constructivist Approach to Translator Education. Manchester: St. Jerome, 2000.

LI, D. Teaching Business Translation: A Task-based Approach. The Interpreter and Translator Trainer, Manchester, 2013, v. 7, n. 1, pp: 1-26. Available at: https://www.tandfonline.com/doi/abs/10.1080/13556509.2013.10798841

LIGHTBOWN, P. Exploring relationships between developmental and instructional sequences in L2 acquisition. In: H. Seliger \& M. Long (Eds.). Classroom-oriented research in second language acquisition. Rowley. MA: Newbury House, 1983, pp. 217-243.

LONG, M. Native speaker/non-native speaker conversation and the negociation of comprehensible input. Applied Linguistics, 1983, v. 4, n. 2, pp. 126-41.

LONG, M. A role for instruction in second language aquisition: Task-based language training. In K. Hyltenstam \& M. Pienemann (Eds.). Modelling and assessing second language acquisition. Clevedon, Avon: Multilingual Matters, 1985, pp. 77-100.

LONG, M. Focus on Form: A design feature in language teaching methodology. In: K. De Bot, R. Ginsbert \& C. Kramsch (Eds.) Foreign language research in cross-cultural perspective. Amsterdam: John Benjamins, 1991, pp. 39-52.

NUNAN, D. Designing Tasks for the Communicative Classroom. Cambridge: Cambridge University Press, 1989.

OCHS, E. Planned and unplanned discourse. Syntax and Semantics, 1979, v. 12, pp. 51-80.

PACTE Group. Building a Translation Competence Model. In: Alves, F. (Ed.) Triangulating Translation: Perspectives in Process Oriented Research. Amsterdam: John Benjamins, 2003, pp. 43-66.

PICA, T. Adult acquisition of English as a second language under different conditions of exposure. Language Learning, 1983, 33, pp. 465-497.

PRABHU, N. (1987). Second Language Pedagogy. Oxford: Oxford University Press. 
RICHARDS, J., PLATT, J., and WEBER, H. Longman Dictionary of Applied Linguitics. London: Longman, 1986.

SAMUDA, V. \& BYGATE, M. Tasks in Second Language Learning. New York: Palgrave Macmillan, 2008.

SKEHAN, P. A framework for the implementation of task-based instruction. Applied Linguistics 17(1). UK: Cambridge University Press, 1996, pp. 542-566.SKEHAN, P. Taskbased Instruction. Language Teach, 2003, 36, pp. 1-14.

WIDDOWSON, H. Context, community and authentic language. TESOL Quarterly, 1998, 32, pp. 705-716.

WILLIS, J. A Framework for Task-based Learning. Harlow, UK: Longman, 1996. Image: http://teknotronic.com/product_images/uploaded_images/profw.jpg

\footnotetext{
${ }^{\text {i }}$ Edelweiss Vitol GYSEL - Doutora (2017) e Mestre (2013) em Estudos da Tradução pela Universidade Federal de Santa Catarina. Bacharel em Letras Inglês (2009) pela mesma instituição. Florianópolis, Santa Catarina, Brasil.

Lattes: http://lattes.cnpq.br/5340634531968579 E-mail: egysel@ gmail.com

ii Here, the definitions of declarative and procedural knowledge are based on Anderson (1983), who states that the declarative knowledge consists in knowing what and is essentially acquired through exposition; differently, the procedural knowledge is knowing how and is acquired through practice.
} 